\title{
Performance of Wild Apricot under Fertigation Practices (Prunus armeniaca L.) in Cold Arid Condition of Ladakh Region
}

\author{
Shabber Hussain ${ }^{1 *}$, Deldan Namgial ${ }^{2}$, Anil Kumar ${ }^{2}$ and T. H. Masoodi ${ }^{2}$ \\ ${ }^{1}$ Department of Fruit Science, KVK, Kargil II, Zanskar, India \\ ${ }^{2}$ (Soil and water conservation) High Mountain Arid Agriculture Research Institute, \\ SKUAST-K, Leh Ladakh, India \\ *Corresponding author
}

\section{A B S T R A C T}

\section{Keywords}

Apricot,

Drip irrigation,

Fertigation,

Plant growth

\section{Article Info}

Accepted:

04 September 2019

Available Online:

10 October 2019
The present investigation entitled "Performance of wild apricot under fertigation practices (Prunus armeniaca L.) in cold arid condition of Ladakh" was carried out at PFDC Farm Leh. The fertigation techniques of water and fertilizers application has provide its superiority, in fruit and vegetable crops, owing to precise and direct application of water in the root zone without wetting the entire area. Fertigation consequences with and without mulch in apricot, one of the most important temperate fruit crops of Ladakh region, have yet not been established. The present investigation was therefore, carried out to investigate the effect of fertigation on growth parameters of apricot. The higher increase in growth parameters under drip fertigation may be attributed to better water and nutrient utilization. The frequent application of water and nutrients might have met the plant requirement during the critical growth periods. On the other hand, under conventional soil fertilization, apricot plants might not have access to these nutrients due to lack of optimum soil moisture condition throughout the growing period beside higher nutrient losses. The result revealed that, effect of fertigation and irrigation level on annual shoot extension growth (ASEG) was significant. $\mathrm{F}_{1}$ (Fertigation-100\% RD) along with $\mathrm{I}_{1}$ (30 minutes) registered significantly maximum increase in ASEG $(46.92 \mathrm{~cm}$ and $45.45 \mathrm{~cm})$. Maximum increase in plant height $(2.02 \mathrm{~m}$ and $1.97 \mathrm{~m})$ were observed under the same treatment, but it's were observed to be statistically non-significant in treatment of irrigation level. Maximum (4.06 $\mathrm{m}$ and $3.83 \mathrm{~m}$ ) canopy volume were observed under treatments F1 (Fertigation-100\% RD) along with $\mathrm{I}_{1}$ (30 minutes), respectively. Application of fertilizers through drip resulted in less fixation of the nutrients in soil and thus higher availability of nutrients and growths in the plant. The fertigation level should be accomplished with $\mathrm{F}_{1}$ (Fertigation-100\% RD) along with $I_{1}$ (30 minutes) to attain higher productivity of plant growth parameters in apricot. Also, it should be considered that an investigation of a longer length should be carried out to draw more conclusive results. So, plants should be tried for at least 3-5 years to bring some confirmation of the above brought results. 


\section{Introduction}

Horticulture plays an important role in the economic prosperity of the Ladakh region, owing to peculiar climate and topographical conditions. Apricot is one of the most important and highly remunerative crops of North Western Himalayan region of India and is generally cultivated in areas situated between 900-3000 meters amsl. Apricot plays an important role in human nutrition, and can be used as a fresh, dried or processed fruit such as frozen apricot, jam, jelly, marmalade, pulp, juice and extrusion products (Mirzaee $e t$ al., 2009). Apricot is a high popular fruit species grown in the Mediterranean countries, and the fruit is highly appreciated in terms of human health.

There is an imperative need to produce more from less arable land and water. The continuous improvement in productivity with efficient management of natural resources is essential for sustainability of any production system. Apart from the economic considerations, it is well known that the adverse effect of injudicious use of water and fertilizers can also have far reaching implications on the environment.

There is thus, a need for technological interventions that will help in minimizing the use of these precious resources and maximizing crop production without any detrimental effects on the environment. The efficiency in the use of water and fertilizers is very low. Among the many techniques of water application, the micro irrigation practices are very efficient and conserving in nature.

Drip irrigation system delivers the water to the plant as per requirement directly to the root zone with high nutrient and water use efficiency (Shirgure et al., 2001). A number of studies in different fruit crops have demonstrated that drip irrigation is superior to conventional basin or other surface irrigation methods in several respects (Chopade and Gorantiwar, 1998, Pampattiwar et al., 1993 and Yargattikar and Itnal, 2003). Fertigation, offers a vast potential for more accurate and timely crop nutrition, preventing the leaching and volatilization losses of nutrients.

The major advantages of fertigation are in saving of the labour, appropriate timing of application of water and nutrients and their uniform distribution (Raina, 2002). Other advantages of fertigation lies in minimum leaching and volatilization losses, higher fertilizer use efficiency besides higher crop yields (Raina et al., 2011).

The scarcity of water resources in Ladakh is well known and is characterized by extremely harsh environment being climatically referred as "cold desert" due to its combined features of arctic and desert climates with diurnal and seasonal fluctuations of $-40^{\circ} \mathrm{C}$ in winter to $+35^{\circ} \mathrm{C}$ in summer, and soils with the range from gravely and sandy loams on the alluvial plains to sandy and silt clay loams on the flood plains of Indus with low organic matter and poor water retention capacity.

This induces the development of studies focused on the optimization and efficiency of irrigation. Lack of assured amount of irrigation water and proper nutrients management are some of the major factors in Ladakh contributing to the low yield levels of apricot.

Though Ladakh region receives very low rain in summer (1000-1200 mm) and snow in winter (1000-1200 mm) however, 80 per cent of the total snowfall and rainfall is concentrated during offseason of cultivation (January - February and July-August) as such, pre and post monsoon water stress is of common occurrence in the region. 
Under such conditions, the available nutrient contents are not utilized efficiently by the plants, when applied through conventional methods under irrigated condition. Steep slopes, undulating topography, shallow soil depth, poor retention of water and nutrients further aggravates the problem, consequently leading to low yields.

The only viable remedy under such conditions is to harvest the rain water, store it and utilize the same through efficient irrigation systems such as Drip.

These result indicates that requirement of water through drip can further be reduced by using suitable mulches. The work carried out at Precision Farming Development Centre Leh on drip irrigation and plastic mulching in vegetable crops has given encouraging results. Such studies however, have not been conducted systematically in the perennial fruit crops.

A critical perusal of documented literature reveals that consequences of drip irrigation and fertigation, in apricot (Prunus armeniaca L.) orchards of Ladakh region have not yet been established. It was therefore, found imperative to study the effect of drip irrigation and fertigation productivity of the wild apricot with the objectives to evaluate effect of drip irrigation and fertigation on tree growth parameters.

\section{Materials and Methods}

The present investigations entitled "performance of wild apricot under mulch and drip irrigation practices" was carried out at the Precision Farming Development Centre farm of HMAARI District Leh Ladakh, Jammu and Kashmir during the years 2017-18. The details of materials used and the methods adopted during the course of investigation are given below.

\section{Geographical location of experimental site}

PFDC Leh Ladakh has an extremely harsh environment being climatically referred as "cold desert" due to its combined features of arctic and desert climates with diurnal and seasonal fluctuations of $-21.5^{\circ} \mathrm{C}$ in winter to $+31.5^{\circ} \mathrm{C}$ in summer during experimentation period. Due to high altitude $(>3319 \mathrm{~m})$ and low humidity $(20 \%)$, the radiation level is amongst the highest in the world (up to 6-7 $\mathrm{Kwh} / \mathrm{mm}$ ). The soils at experimental site range from gravely and sandy loams with alkaline soils. The average precipitation was $6.5 \mathrm{~mm}$ mostly received during MarchSeptember.

The experimental orchard is situated at an elevation of $3319 \mathrm{~m}$ above mean sea level and lies at $33^{\circ} 56^{\prime} \mathrm{N}$ latitude and $77^{\circ} 43^{\prime} \mathrm{E}$ longitude. The total precipitation of $35.5 \mathrm{~mm}$ was received during entire experimental periods during 2017.

Drip system comprised three emitters in each plant, placed at a distance of $25 \mathrm{~cm}$ from tree trunk. The operating pressure of drip system was $1.2 \mathrm{~kg} \mathrm{~cm}^{-2}$. The present investigation was carried out conducting field experiment in the orchard wherein, fertigation and drip irrigation level treatments were tried in triplicate in a 'Complete Randomised Block Design'.

The uniformity of drip system recorded at the beginning of experiment was $90-95 \%$.

\section{Treatment details}

$\begin{array}{ll}\text { Fertigation Level } & \text { Irrigation Level } \\ \text { F1: Fertigation-100\% } & \text { I1: } 30 \text { minutes } \\ \text { RD } & \text { I2: } 22 \text { minutes } \\ \text { F2: Fertigation- } 80 \% & \text { I3: } 11 \text { minutes } \\ \text { F3: Fertigation-60\% } & \\ \text { F4: Conventional soil } \\ \text { fertilization-(RD*) } \\ \begin{array}{l}* \text { Full grown apricot tree (9 years): } \mathrm{N}: \quad \mathrm{P}_{2} \mathrm{O}_{5}: \mathrm{K}_{2} 0: \\ \text { 500:250:700 g/tree }\end{array}\end{array}$


Treatment combinations

F1 I1 F2 I1 $\quad$ F3 I1 $\quad$ F4 I1

$\begin{array}{llll}\text { F1 I2 } & \text { F2 I2 } & \text { F3 I2 } & \text { F4 I2 }\end{array}$

$\begin{array}{llll}\text { F1 I3 } & \text { F2 I3 } & \text { F3 I3 } & \text { F4 I3 }\end{array}$

\section{Method of fertigation}

Fertigation was done through fertigation tank in 7 equal split applications at 7days' intervals, starting with effect from $3^{\text {rd }}$ week of March of experimental year and continued till $4^{\text {th }}$ week of April. The water soluble fertilizer was used for fertigation.

To meet the NPK requirement of different treatments, WSF was supplemented with urea and Murate of Potash (MOP). In the experimental year 2018-19, the quantity of urea, DAP and MOP was computed to be 155 , 77 and $166 \mathrm{gm} /$ tree/split. After each fertigation, drip system was thoroughly flushed.

\section{Conventional soil fertilization}

Soil fertilization treatments were given as per recommended package and practices (Verma et al., 2002). The $\mathrm{N}$ containing fertilizer was applied in the tree basin in two equal split applications, half in the month of Marchand remaining half after one month of first application. The $\mathrm{P}_{2} \mathrm{O}_{5}$ and $\mathrm{K}_{2} \mathrm{O}$ containing fertilizers were applied in the $3^{\text {rd }}$ week of March during the year of study.

\section{Mulch}

The entire trees were uniformly mulched during the start of experiment i.e. $3^{\text {rd }}$ week of March with the help of polythene except control one.

\section{Materials}

Nine -years-old wild apricot trees of uniform size and vigour receiving of uniform cultural practices were selected for the experimentation. Treatments and replications were randomly assigned with a single plot size.

\section{Field preparations}

Basins of experimental trees were properly levelled before conducting the experiment.

\section{Method and time of irrigation}

A field experiment was conducted in apricot orchard during the year 2018-19 at Precision Farming Development Centre farm of HMAARI Leh Ladakh. Wild apricot was planted at recommended spacing in squire system of planting. Recommended doses of FYM and NPK were not applied till the start of experiment. The plants were treated with drip irrigation methods, mulching and fertigation.

The plant water requirement was calculated on the basis of daily pan evaporation. All the plants were irrigated on regular basis. There were three drip irrigation level i.e. 30, 22 and 11 minutes.

\section{Growth characteristics}

\section{Annual shoots extension growth (cm)}

For measuring shoot extension growth, 15 shoots from current season's growth of each plant were selected from all the 4 geographical directions and top of tree (3 from each) randomly. The length of each shoot was measured from the point of growth initiation with the help of measuring tape. The shoot growth was expressed as $\mathrm{cm}$ based on their averages. 


\section{Plant height (m)}

The height of each experimental plant was measured with the help of measuring tap using a long stick from the ground to the top and expressed in meters.

\section{Trunk girth (mm)}

The trunk girth was measured with the help of a digital caliper $(0-300 \mathrm{~mm})$ after the completion of experiment. The values have been expressed in millimeter.

\section{Plant spread (m)}

Plant spread of each experimental plant was measured from North-South and East-West directions.

The average of both the directions were taken as spread of the plant at the end of growing season and expressed in meters.

\section{Plant volume $\left(\mathrm{m}^{3}\right)$}

The average tree volume for each treatment was calculated from height and spread measurements according to the formula given by Westwood (1993).

For a tree that was taller than wide (prolate spheroid):

Tree volume $=4 / 3 \pi \mathrm{ab}^{2}$

For a tree that was wider than tall:

$$
\text { Tree volume }=4 / 3 \pi \mathrm{a}^{2} \mathrm{~b}
$$

Where,

$\begin{array}{ll}\mathrm{a} & =1 / 2 \text { of the major axis (height) } \\ \mathrm{b} & =\quad 1 / 2 \text { of the minor axis (spread) } \\ \pi & =\quad 3.142\end{array}$

\section{Leaf area $\left(\mathrm{cm}^{2}\right)$}

Twenty-five leaves were collected from middle portion of the branch on all four directions randomly from each experimental tree during August and leaf area was measured with the help of Systronic Leaf Area Meter11. The results were expressed in centimeter square.

\section{Statistical analysis}

The data recorded under study were subjected to statistical analysis according to randomized complete block design. The statistical analysis of the data was carried out as per the method described by Gomez and Gomez (1984). The treatment effects were tested at 5 per cent level of significance.

\section{Results and Discussion}

The present investigation entitled "Performance of wild apricot under fertigation practices (prunus armeniacaL.)" were aimed to investigating the effect of fertigation on growth characteristic under fertigation. The results obtained on these aspects are presented under the following heads

\section{Annual shoot growth and Plant heightof wild apricot}

The data on the effect of different treatments on annual shoot growth recorded during the observation are presented in Table 1. Treatment F1 (Fertigation-100\% RD) gave the maximum $(46.92 \mathrm{~cm})$ growth of annual shoot extension growth, which was statistically at par $(45.29 \mathrm{~cm})$ in treatment F2 Fertigation$80 \%$ whereas, the minimum $(40.02 \mathrm{~cm})$ was recorded in treatment F4 (Conventional soil fertilization). The 30-minute irrigation level (I1) resulted in the maximum $(45.45 \mathrm{~cm})$ growth of annual shoot extension growth. The interaction effect of drip fertigation practices 
on annual shoot extension growth was nonsignificant as has been illustrated in Table 1 . The perusal data in Table 1 indicate that plant height were significantly affected by the different treatments. F1 (Fertigation-100\% RD) resulted maximum $(2.02 \mathrm{~m})$ height of apricot plant, whereas, the minimum $(1.88 \mathrm{~m})$ height of plant was obtained in F4 (Conventional soil fertilization). The I1(30minute irrigation level) among the different irrigation level and the interaction effect was non-significant.

This may be attributed to the fact that, nutrient and water are the key factor for maximum growth production. Under fertigation condition, timely availability of water along with fertilizer nutrients during most critical period of growth might have resulted in better root growth, nutrient uptake and thereby resulting in higher growth parameters.

Our results regarding the effect of fertigation treatment on annual shoot extension growth are in accordance with the results of Suman (2003) in apricot. Fertigation significantly increased annual shoot growth and plant height over conventional fertilization also reported by Bindra (2012) in apricot. Significant effects of drip fertigation in terms of higher growth parameters compared to conventional soil fertilization have also been described by Neilsen andNeilsen (2006) and Treder (2006).

\section{Trunk girth and east west spread of wild apricot}

Data pertaining in Table 2 revealed that maximum trunk girth $(57.91 \mathrm{~mm})$ was recorded with F1 (Fertigation-100\% RD). I1(irrigation level @ 30 minute), among different irrigation level produced maximum trunk girth $(56.97 \mathrm{~mm})$. In the interaction effect, treatment $\mathrm{F} 1$ along with $\mathrm{I1}$ resulted in the maximum $(58.67 \mathrm{~mm})$ trunk girth of apricot plant, whereas the trunk girth was minimum $(54.47 \mathrm{~mm})$ in $\mathrm{F} 4$ along with I3.The data in Table 2 indicates that among the different treatments, plant spread in respect of east west spread was highest $(2.00 \mathrm{~m})$ in treatment F1 (Fertigation-100\% RD). Among different irrigation level east west plant spread was highest $(1.92 \mathrm{~m})$ in treatment I1(irrigation level@30 minute).

Treatment F1 along with $\mathrm{I} 1$ resulted the highest $(2.06 \mathrm{~m})$ east west spread in apricot plant.Fertigation@100\% recommended dose along with irrigation level @ 30 minute may have increased the nitrogen uptake with simultaneous increase in phosphorous and potassium uptake due to its synergistic effect resulting in increased the rate of various physiological and metabolic processes in the plant system, which ultimately increasing in trunk growth and plant spread. This result is in agreement with the finding reported by Bindra (2012), Suman (2003) in apricot, and Meheriuk et al., (1995).

\section{North - South spread and plant volume of wild apricot}

The North - South spread of wild apricot as depicted in Table 3 was significantly affected by fertigation treatments and irrigation level. The North - South spread was maximum (1.97 m) inF1 (Fertigation-100\% RD), which was statistically at par $(1.94 \mathrm{~m})$ with that in treatment F2 (Fertigation-80\%). Among different irrigation level, the maximum (1.95 m)spread was recorded in I1 (irrigation level (a 30 minute). The interaction effect of drip fertigation and irrigation level on North South spread of wild apricot was nonsignificant. The canopy volume of wild apricot was significantly affected by fertigation treatment and irrigation level as shown in Table 3. F1 (Fertigation-100\% RD) produce maximum $(4.01 \mathrm{~m})$ plant volume followed by that $3.96 \mathrm{~m}$ in treatment $\mathrm{F} 2$ (Fertigation-80\%). 
Table.1 Effect of drip fertigation practiceson annual shoot extension growth and plant heightof wild apricot

\begin{tabular}{|c|c|c|c|c|c|c|c|c|}
\hline \multicolumn{5}{|l|}{ ASEG (cm) } & \multicolumn{4}{|c|}{ Plant height (m) } \\
\hline Treatment & I1 & I2 & I3 & Mean & I1 & 12 & I3 & Mean \\
\hline F1 & 49.00 & 47.66 & 44.10 & 46.92 & 2.04 & 2.02 & 1.99 & 2.02 \\
\hline F2 & 46.79 & 46.81 & 42.27 & 45.29 & 2.01 & 2.00 & 1.98 & 2.00 \\
\hline F3 & 45.85 & 45.09 & 41.22 & 44.05 & 1.94 & 1.92 & 1.90 & 1.92 \\
\hline F4 & 40.17 & 39.82 & 40.06 & 40.02 & 1.90 & 1.88 & 1.87 & 1.88 \\
\hline Mean & 45.45 & 44.85 & 41.91 & & 1.97 & 1.96 & 1.94 & \\
\hline Factors & & C.D. & & & \multicolumn{4}{|l|}{ C.D. } \\
\hline \multicolumn{2}{|c|}{ Irrigation level (IL) } & \multicolumn{3}{|l|}{1.71} & \multicolumn{4}{|l|}{ N.S. } \\
\hline \multicolumn{2}{|c|}{ Fertigation level (FL) } & \multirow{2}{*}{\multicolumn{3}{|c|}{1.99}} & \multicolumn{4}{|l|}{0.04} \\
\hline \multicolumn{2}{|c|}{ (IL) $\times(F L)$} & & & & N.S. & & & \\
\hline
\end{tabular}

Table.2 Effect of drip fertigation practiceson trunk girt hand East-West (EW) spread of wild apricot

\begin{tabular}{|l|l|l|l|l|l|l|l|l|}
\hline \multicolumn{2}{|l}{ Trunk girth (mm) } & & & \multicolumn{4}{l|}{ E-W spread (m) } \\
\hline Treatment & I1 & I2 & I3 & Mean & I1 & I2 & I3 & Mean \\
\hline F1 & 58.67 & 58.19 & 56.88 & $\mathbf{5 7 . 9 1}$ & 2.06 & 2.02 & 1.92 & $\mathbf{2 . 0 0}$ \\
\hline F2 & 58.00 & 57.29 & 56.32 & $\mathbf{5 7 . 2 0}$ & 1.97 & 1.97 & 1.91 & $\mathbf{1 . 9 5}$ \\
\hline F3 & 56.33 & 55.13 & 54.32 & $\mathbf{5 5 . 2 6}$ & 1.87 & 1.84 & 1.85 & $\mathbf{1 . 8 5}$ \\
\hline F4 & 54.89 & 54.39 & 54.12 & $\mathbf{5 4 . 4 7}$ & 1.80 & 1.77 & 1.82 & $\mathbf{1 . 8 0}$ \\
\hline Mean & $\mathbf{5 6 . 9 7}$ & $\mathbf{5 6 . 2 5}$ & $\mathbf{5 5 . 4 1}$ & & $\mathbf{1 . 9 2}$ & $\mathbf{1 . 9 0}$ & $\mathbf{1 . 8 8}$ & \\
\hline Factors & & C.D. & & & & C.D. & & \\
\hline Irrigation level (IL) & N.S. & & & & N.S. & & \\
\hline Fertigation level (FL) & 2.66 & & & & 0.12 & & \\
\hline (IL) x (FL) & N.S. & & & & N.S. & & \\
\hline
\end{tabular}

Table.3 Effect of drip fertigation practiceson North - South (N-S) spread and plant volume of wild apricot

\begin{tabular}{|l|l|l|l|l|l|l|l|l|}
\hline \multicolumn{1}{|l|}{ N-S spread (m) } & \multicolumn{9}{|c|}{ Canopy volume (m) } \\
\hline Treatment & I1 & I2 & I3 & Mean & I1 & I2 & I3 & Mean \\
\hline F1 & 2.00 & 1.98 & 1.94 & $\mathbf{1 . 9 7}$ & $\mathbf{4 . 4 1}$ & $\mathbf{4 . 0 4}$ & $\mathbf{3 . 7 4}$ & $\mathbf{4 . 0 6}$ \\
\hline F2 & 1.98 & 1.97 & 1.88 & $\mathbf{1 . 9 4}$ & $\mathbf{3 . 9 4}$ & $\mathbf{3 . 9 2}$ & $\mathbf{3 . 5 6}$ & $\mathbf{3 . 8 1}$ \\
\hline F3 & 1.95 & 1.94 & 1.87 & $\mathbf{1 . 9 2}$ & $\mathbf{3 . 8 4}$ & $\mathbf{3 . 3 3}$ & $\mathbf{3 . 3 0}$ & $\mathbf{3 . 4 9}$ \\
\hline F4 & 1.85 & 1.85 & 1.86 & $\mathbf{1 . 8 5}$ & $\mathbf{3 . 1 4}$ & $\mathbf{2 . 9 9}$ & $\mathbf{3 . 1 7}$ & $\mathbf{3 . 1 0}$ \\
\hline Mean & $\mathbf{1 . 9 5}$ & $\mathbf{1 . 9 4}$ & $\mathbf{1 . 8 9}$ & & $\mathbf{3 . 8 3}$ & $\mathbf{3 . 5 7}$ & $\mathbf{3 . 4 4}$ & \\
\hline Factors & & C.D. & & & & C.D. & & \\
\hline Irrigation level (IL) & $\mathbf{0 . 0 4}$ & & & & N.S. & & \\
\hline Fertigation level (FL) & $\mathbf{0 . 0 5}$ & & & & $\mathbf{0 . 0 4}$ & & \\
\hline (IL) $x$ (FL) & N.S. & & & & N.S. & & \\
\hline
\end{tabular}


Table.4 Effect of drip fertigation practiceson leaf areaof wild apricot

\begin{tabular}{|l|l|l|l|l|}
\hline \multicolumn{5}{|l|}{ Leaf area $\left(\mathbf{c m}^{\mathbf{2}}\right)$} \\
\hline Treatment & I1 & I2 & I3 & Mean \\
\hline F1 & 19.94 & 19.87 & 19.18 & $\mathbf{1 9 . 6 6}$ \\
\hline F2 & 19.47 & 19.44 & 18.30 & $\mathbf{1 9 . 0 7}$ \\
\hline F3 & 17.48 & 17.53 & 17.40 & $\mathbf{1 7 . 4 7}$ \\
\hline F4 & 16.18 & 15.91 & 15.85 & $\mathbf{1 5 . 9 8}$ \\
\hline Mean & $\mathbf{1 8 . 2 7}$ & $\mathbf{1 8 . 1 9}$ & $\mathbf{1 7 . 6 8}$ & \\
\hline Factors & & C.D. & & \\
\hline Irrigation level (IL) & $\mathbf{0 . 4 5}$ & & \\
\hline Fertigation level (FL) & $\mathbf{0 . 5 2}$ & & \\
\hline (IL) x (FL) & N.S. & & \\
\hline
\end{tabular}

Among irrigation level and interaction effect on canopy volume was statistically non-significant. Increased fertilizers dose and irrigation level may be attributed to the significant improvement in the tree vigour as reflected in terms of plant spread and canopy volume.

These result are in agreement with the finding of Bindra (2012), Suman (2003) in apricot and Bussi et al., (1991) in peach and Klein et al., (1989).They observed that shoot extension growth and pruning weight were maximum under drip fertigation and maintained a positive correlation with the amount of fertilization.

\section{Leaf areaof wild apricot}

Leaf area was significantly affected by different fertigation and irrigation level according to Table 4. Maximum $\left(19.66 \mathrm{~cm}^{2}\right)$ leaf area was recorded in treatment F1 (Fertigation-100\% RD) followed by that $19.07 \mathrm{~m}$ in treatment $\mathrm{F} 2$ (Fertigation-80\%), while the minimum leaf area was observed in F4 (Conventional soil fertilization-(RD).

Among different irrigation level, maximum $\left(18.27 \mathrm{~cm}^{2}\right)$ leaf area was observed in I1 (irrigation level@30 minute).

The leaf area of wild apricot was statistically non-significant in the interaction effect of fertigation along with irrigation level.The higher increase in growth parameters under drip fertigation may be attributed to better water and nutrient utilization.

These results are in agreement with the finding of Bindra (2013), Suman (2003) in apricot Yosef (1999) and Hipps (1992). They reported that drip fertigation increased the nutrient use efficiency by minimizing leaching losses. On the other hand, under conventional soil fertilization, trees might not have access to these nutrients due to lack of optimum soil moisture condition throughout the growing period besides higher nutrient losses.

\section{Acknowledgment}

The authors are grateful to NCPAH (National Committee on Plasticulture Application in Horticulture) and Principal Investigation of PFDC (Precision Farming Development Centre Leh Ladakh India) for their assistance and grants.

\section{References}

Bindr, M., 2012. Effect of drip fertigation and mulch on soil nutrient status and growth parameters of apricot (Prunus armeniaca L.) cv. Harcot. M. Sc. Thesis, College of forestry $\mathrm{Dr}$ Yashwant Singh Parmar University of Horticulture and Forestry, Nauni, Solan (H.P.).

Bussi, C, Huguet, J.G. and Defrance, H. 1991. Fertilization scheduling in peach orchard 
under trickle irrigation. Journal of Horticultural Science 66(4): 487-493.

Chopade, S.O. and Gorantiwar, S.D. 1998. Effect of various methods of irrigation on growth and yield of pomegranate. Annals Plant Physiology 12:(2):98-102.

Gomez, K.A. and Gomez, A.A. 1983. Statistical procedures for agricultural research. Johan Wiley and Sons, New York.

Hipps. N.A. 1992. Fertigation of newly planted 'Queen Cox'/M.9 apple trees: establishment, early growth and precocity of cropping. Journal of Horticultural Science 67(1): 25-32.

Klein, I., Levin, I., Bar, B., Assaf, R. and Berkovitz, A. 1989. Drip nitrogen fertigation of 'Starking Delicious' apple trees. Plant and Soil 119: 305-314.

Meheriuk, M., Neilsen, G.H. and Hogue, E.J. 1995. Influence of nitrogen fertilization and orchard floor management on yield, leaf nutrition and fruit quality of 'Fairhaven' peach. Fruit Varieties Journal 49: 204-211.

Mirzaee, E., Rafiee, S., Keyhani, A., Djom-Eh, Z.E., 2009. Physical properties of apricot to characterize best post harvesting options. Australian Journal of Crop Science 3(2), 95-100.

Neilsen, G. and Neilsen, D. 2006. Strategies for nutrient and water management of high density apple orchards on coarse-textured soils. Annals of Warsaw Agricultural University- Horticulture and Landscape Architecture 27: 181192.

Pampattiwar, P. S., Suryavanshi, S.N., Gorantiwar, S.D. and Pingale, L.V.1993. Drip irrigation for pomegranate. Maharashtra Journal of Horticulture 7(1):46-50.

Raina, J. N., Tarika, S. and Suman, S. 2011. Effect of drip fertigation with different fertilizers on nutrient distribution in soil, leaf nutrient content and yield of apricot (Prunus armeniaca L.). Journal of the Indian Society of Soil Science 59: 268-277.

Raina, J. N. 2002. Drip irrigation and fertigation: Prospects and Retrospect's in temperate fruit production: In: Enhancement of temperate fruit production in changing climate. $\mathrm{Ed}(\mathrm{s}) \mathrm{K}$. K. Jindal and D. R. Gautam. University of Horticulture and Forestry, Solan. pp. 296-301.

Shirgure, P.S., Srivastava, A.K. and Singh, S. 2001. Effect of drip micro jet and basin irrigation methods on the growth, soil and leaf nutrient changes in acid lime. Indian Journal of Soil Conservation 29: 229-234.

Suman, S. 2003. Studies on nitrogen fertigation through drip in apricot cv. New castle. M.Sc. Thesis, College of Forestry Dr Yashwant Singh Parmar University of Horticulture and Forestry, Mauni, Solan (H.P).

Treder, W. 2006. Influence of fertigation with nitrogen and a complete fertilizer on growth and yielding of Gala apple trees. Journal of fruit and Ornamental Plant Research 14: 143-154.

Verma, H. S. R. and Sharma, P. L. 2002. Package of practices for fruit crops. Directorate of Extension Education Dr Yashwant Singh Parmar University of Horticulture and Forestry, Mauni, Solan (H.P).

Westwood, M. N. 1993. Temperate zone Pomology. Timber Press, Portland, Oregaon. pp. 223.

Yargattikar, A.T. and Itnal, C.J. 2003. Studies on water requirement during early growth phase of ber through drip irrigation. Karnataka Journal of Agricultural Science 16(1):17-21.

Yosef, B.B. 1999. Advances in fertigation. Advance in Agronomy 65: 1-77.

\section{How to cite this article:}

Shabber Hussain, Deldan Namgial, Anil Kumar and Masoodi, T. H. 2019. Performance of Wild Apricot under Fertigation Practices (Prunus armeniaca L.) in Cold Arid Condition of Ladakh Region. Int.J.Curr.Microbiol.App.Sci. 8(10): 268-276.

doi: https://doi.org/10.20546/ijcmas.2019.810.028 